\title{
Discrete observations of the spatial distributions of the Helix aspersa snail in an outdoor system
}

\author{
Olga González, Gladys Pérez Camargo, Macarena Membiela, Diana Frezza, \\ Norberto Bartoloni, and Carlos Vieites \\ Facultad de Agronomía, Universidad de Buenos Aires. Avda. San Martín 4453. Buenos Aires, Argentina.
}

\begin{abstract}
O. González, G. Pérez Camargo, M. Membiela, D. Frezza, N. Bartoloni, and C. Vieites. 2009. Discrete observations of the Helix aspersa land snails' spatial distribution in an outdoor system. Cien. Inv. Agr. 36(1):123-130. In this study, adult Helix apersa land snails with previously established periodicity were observed at three densities in their finishing stage in order to contribute to the body of knowledge about spatial distribution and certain behavior patterns in an outdoor system. From November 8 to December 18, 2006, snails that were in their final fattening phase were grouped at three densities $\left(50\right.$ snail $\cdot \mathrm{m}^{-2}, 100$ snail $\cdot \mathrm{m}^{-2}, 200$ snail $\cdot \mathrm{m}^{-2}$ ) and randomly placed in nine cubicles, with three replicates of each density. Twelve observations of the snail behavior were made between 12 am and $1 \mathrm{pm}$. The categories selected as "discrete acts" include: observing the snails in the shelters, on Swiss chard leaves (Beta vulgaris), adhered to the netting, on the balanced feed, on the water supply tray, and on the ground. A statistical analysis employing marginal and partial frequency tests was completed on the density $\mathrm{x}$ category $\mathrm{x}$ time interactions. It was concluded that around midday, the majority of the snails remained in the artificial shelters and on the Swiss chard monoculture leaves. In addition, differences were not detected for the rest of the categories in regard to the spatial distribution of the individuals in the three densities analyzed. If lower densities than the ones most commonly employed in studies $\left(200\right.$ snail $\left.\cdot \mathrm{m}^{-2}\right)$ are used in an open outdoor system in the fattening stage, the individuals will use the available space in a similar way, thereby exhibiting similar behavior patterns.
\end{abstract}

Key words: Helix aspersa, heliciculture, snails, spatial distribution.

\section{Introduction}

Mollusks are the second most frequently found group of animals, after arthropods, in wild terrestrial fauna. Their great diversity and capacity for organizing a wide spectrum of biotypes resides in this species' adaptive capacity. Although mollusks have not been able to control

Received 23 June 2008. Accepted 25 September 2008. Corresponding author: ogonzale@agro.uba.ar. the desiccation of their body surface, resulting in the loss of a considerable quantity of water in the production of slime for their movement, they have developed mechanisms that allow them to survive in conditions of drought, scarcity of food, high or low temperatures, and excessive sunshine and/or wind.

The life cycle of the land snail (Helix aspersa Müller) presents phases of activity and inactivity as a response to environmental variations. When facing adversity, they enter into a lethargic state by selecting a protected place, going 
inside their shell and maximally reducing their metabolic activity. Emergence from this lethargic state leads to intense feeding, movement, and reproduction (Arrébola Burgos, 2004, 2001; Madec et al., 2000).

The geographic distribution of land snails is regulated, in part, by climatic conditions, latitude and the nature of the substrate upon which they reside. Man has introduced certain species of snails into zones in which they wouldn't have arrived by natural distribution. In these zones, they are frequently subject to intense extractions that condition the survival of some species (Arrébola Burgos, 2004). The extraction of land snails from the natural environment is caused by the demand for their meat by populations with cultural roots in the consumption or preference of exotic products (Vieites et al., 2007; Arrébola Burgos, 2001).

The production of land snails in captivity for human consumption arose as an alternative to extraction from the natural habitat (González et al., 2005; Dupont-Nivet et al., 2000). However, the expected results were not obtained since it has been very difficult to achieve a commercial scale of production (Vieites et al., 2007; González et al., 2005).

The three systems of snail production commonly employed are: closed or indoor, mixed, and open or outdoor (Vieites et al., 2006; Arditi et al., 2003). In these systems, the snails are placed in environments that are commonly different from the natural ones.

The most used system in Argentina is outdoor production, which consists of outdoor pens with planted vegetation that are sometimes supplemented with balanced feed or additional plants aside from those in the pens (San Román et al., 2004). This production system is the most similar to the natural environment. However, the marked production differences between wild snails and raised snails impedes the satisfaction of market demands (González et al., 2007).

Perea Muñoz et al. (2005), citing Savage (1931), define habitat as the physical or geographic place that provides adequate conditions for the life of an organism. "Habitat" corresponds to natural environments inhabited by native and introduced species and to environments habitually provided by man for different purposes, among them, reproduction in captivity (González, 2007). The study of species distribution in relation to the habitat, allows for the discovery of significant differences between use and availability. In regard to land snails, the natural habitat presents little opportunity for dispersal. This is associated with an intrinsic behavior called "homing behavior" (Arnaud et al., 2003).

Individual behavior is strongly influenced by the natural surroundings and specific intra- and inter-relationships of the conformed groups in both natural and captive environments. If the environment is propitious, the stimulus perceived by the living organisms provokes favorable responses, expressed as beneficial individual and group actions. In hostile environments, the manifestations of the individuals will be related to situations of anxiety and stress (González, 2007; Grandin, 2002; Navarro Mestre, 2000).

According to Perea et al. (2006), if the habitat of snails in captivity is unfavorable, growth is inhibited and the mortality rate increases. In breeding pens, zones with high density of individuals are frequently observed, as well as other scarcely inhabited zones. This may be due to selection of microhabitats according to the availability of food; if food is scarce, the individuals restrict their spatial distribution to a radius near the source of food. This causes an excess of individuals in one area at the detriment to other individuals. According to other authors (San Román et al., 2004; Lagrifa, 2003), in an adverse environment, the specimens try to escape by adhering to the containment nets of the premises. An increase in escape attempts is seen when the quantity of edible plants decreases.

Description of animal behavior is accomplished through the observation of continuous processes or discrete acts. Continuous observation provides a large quantity of information that can be applied to the activities of the group. Discrete 
information describes a limited number of behavioral expressions classified in categories that are grouped by function (e.g. eating, drinking, sleeping, mating, and aggression, among others). Discrete observations are seen at predetermined and regular time periods, by registering each behavior at a specific moment, without considering the duration of the studied activities (Slideshare, 2007). When the observations are determined to be complete (i.e. more observation time will not add any new behavioral expressions), the list of registries is considered to be an ethogram or list of the species' behavioral patterns (Lahitte et al., 2002).

The density of snails in the fattening stage that were mostly raised in an outdoor system was 200 snail $\cdot \mathrm{m}^{-2}$, far above that of their natural habitat. For example, in the Santa Lucía region of Spain, 200 snail $\cdot \mathrm{m}^{-2}$ were estimated (San Román et al., 2004; Arrébola et al., 2004). Baur (1992) estimated that the density of another land snail species (Arianta arbustorum) was 0.5 to 20 snail $\cdot \mathrm{m}^{-2}$, depending on the characteristics of the habitat (ditches, crop fields, or natural fields).

Perea et al. (2006) emphasize that terrestrial and aquatic mollusks select protective microhabitats to decrease environmental stress. Land snails reject hot and dry habitats, which is the reason it is a good idea to provide them with protective shelters. The homogeneous distribution of individuals in outdoor breeding pens maximizes the use of the available habitat and minimizes the risk of sanitary deficiencies due to overpopulation. The authors of this work propose the inclusion of various intercalated plant layers to be used as shelter, useful surface area, and food.

With the objective of determining if the distribution of snails in the habitat provided differs according to the quantity of individuals per unit of surface area in an outdoor production system, the spatial distribution of adult snails (H. aspersa) at three densities was studied along with some behavioral patterns in the fattening stage.

\section{Materials and methods}

\section{Management conditions}

Nine cubicles of $1 \times 1 \times 1 \mathrm{~m}$ were built (three per premise) inside three $3 \times 13 \mathrm{~m}$ pens. In each cubicle, three $50 \times 15 \mathrm{~cm}$ boards were placed at a $45^{\circ}$ angle in relation to the ground, making an artificial shelter surface in addition to the plant cover. Fifty percent medium shading netting was used on the perimeter and roof. A sprinkling irrigation system was used; the control of escaping snails was foreseen as well as the possible presence of predators. For feeding and plant shelter, Swiss chard (Beta vulgaris) was transplanted. A supplement of balanced feed given to egg laying hens was provided ( $(\mathrm{Ga}$ nave, Argentina (González et al., 2008)).

\section{Experimental population}

Considering that the recommended density for an open outdoor system is 200 snail. $\mathrm{m}^{-2}$ in the fattening stage (San Román et al, 2004; Lagrifa, 2002), the spatial distribution and some behaviors at this density were studied at a pre-established time set between 12 am and $1 \mathrm{pm}$. We evaluated whether a lesser quantity of individuals per surface unit (50 and 100 snail. $\mathrm{m}^{-2}$ ) produced considerable differences in spatial distribution. Between November 8 and December 18, 2006, land snails were randomly placed in the nine cubicles with three repetitions of 50,100, and 200 snail $\cdot \mathrm{m}^{-2}$ in the final fattening stage. During this period, 12 observations were made by previously trained evaluators who tried to cause minimal disturbance at the time of data gathering (Lahitte et al., 2002; Slideshare, 2007).

\section{Evaluation}

Six categories were selected as a series of discrete actions that corresponded to observation of the specimens, namely: in the shelters ("In the shelters"), on the leaves of the Swiss chard B. vulgaris ("On the leaves"), adhered to the medium shade netting ("On the netting"), on the 
balanced feed tray ("On the feed"), on the water supply tray ("In the water"), and on the ground ("On the ground").

\section{Design and statistical analysis}

The snails were distributed in a completely random manner into one of the three treatments to adjust the population density to 50 , 100 , and 200 snail $\cdot \mathrm{m}^{-2}$, with three replicates at each density.

The frequencies of the registry for the different days were statistically analyzed using the marginal and partial frequencies test through the interactions of density $x$ category $x$ time $(p<$ 0.35). A log-linear analysis (Agreste, 2007) was used that allowed for the breakdown of the total value of $\chi^{2}$ into sources of variation (factors) in the same manner as in the classic ANOVA. In this case, said factors were density, category, and time.

\section{Results and discussion}

In the midday observations (12:00 am to $1: 00$ $\mathrm{pm})$, the majority of specimens remained in the plant and/or artificial shelters (Figure 1). Perea et al. (2006) indicated that the resting phase takes place in artificial or natural shelters, which could be interpreted as a protection strategy when facing environmental stress and predation. From the scanning (completed 12 times), it was verified that with 200 snail. $\mathrm{m}^{-2}, 70 \%$ of the individuals remained on the leaves and in the artificial shelters. Seventy-six and $78 \%$ of the individuals remained on the leaves and in the shelters when a density of 100 and 50 snail $\mathrm{m}^{-2}$ was used, respectively.

The interactions between the density, the category, and the time corresponded to $\chi^{2}=59.34$, g.l. $=56, \mathrm{p}<0.35$. No significant interactions were detected between the density and the time or between the density and the category. However, when taking the three densities together, the time $\mathrm{x}$ category interaction (g.1. $28 ; \chi^{2}=72.70$; $\mathrm{p}<0.000008$ ) showed highly significant differences in regard to the average frequencies in the

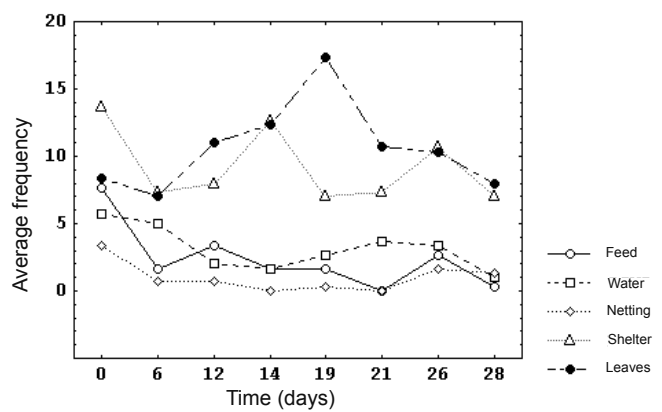

Figure 1. Average frequencies of land snail (Helix aspersa) distribution determined between 12 am and $1 \mathrm{pm}$ for the categories: feed, water, Shelter, leaves, and netting. Averages of 3 densities 20, 100, and 200 snails $\cdot \mathrm{m}^{-2}$.

categories, Shelter (4) and Leaves (5) (Figure 1). For both of these categories, the percentage of visualized individuals was $70 \%$ (200 snail $\left.\mathrm{m}^{-2}\right)$, $76 \%\left(100\right.$ snail $\left.\cdot \mathrm{m}^{-2}\right)$, and $78 \%\left(50\right.$ snail $\left.\cdot \mathrm{m}^{-2}\right)$.

It should be considered that the snails were feeding on the leaves or sheltered at the time of observation. It is known that midday is when snails show less activity and seek protection (San Román et al., 2004). However, the reason it is presumed that some of the snails were feeding is reinforced upon verification that between 9 and $16 \%$ of the individuals were classified in the food category since they were seen on the balanced feed trays.

Perea et al. (2006) recommend using plants in outdoor pens as sources of shelter, useful surface area, and food, which allows for increase in the density of the reproduction. These authors (Perea et al., 2006) proposed a park structure with several layers of intercalated plants and without additional shelters. This proposal may contradict that of other authors who recommend using monoculture techniques and balanced feed, with shelters added to the environment in the latter case (Vieites et al., 2007; González et al., 2008). This facilitates the management of plant cultivation since there are not a variety of species requiring different vegetative conditions. The shelters increase the available space and make it possible for the snails to protect themselves from extreme temperature and humidity values. 
Table 1. Number of snails (Helix aspersa) observed at 12 sampling times during midday hours (12 am to $1 \mathrm{pm}$ ), by category and initial densities.

\begin{tabular}{|c|c|c|c|c|c|c|}
\hline & \multicolumn{6}{|c|}{ Initial density, snail $\cdot \mathrm{m}^{-2}$} \\
\hline & \multicolumn{2}{|c|}{200} & \multicolumn{2}{|c|}{100} & \multicolumn{2}{|c|}{50} \\
\hline Category & Snails, no. & $\%^{1}$ & Snails, no. & $\%^{1}$ & Snails, no. & $\%^{1}$ \\
\hline Ground & 30 & 8.64 & 4 & 3.14 & 9 & 6.30 \\
\hline Food & 32 & 9.22 & 6 & 4.72 & 8 & 5.60 \\
\hline Water & 32 & 9.22 & 20 & 15.74 & 13 & 9.10 \\
\hline Shelter & 130 & 37.46 & 30 & 23.6 & 52 & 36.36 \\
\hline Leaves & 114 & 32.85 & 67 & 52.7 & 59 & 41.25 \\
\hline Netting & 9 & 2.59 & 0 & 0 & 2 & 1.40 \\
\hline
\end{tabular}

${ }^{1}$ Percentage by category in relation to the total number of individuals seen in each category.

In the three densities analyzed, 3 to $9 \%$ of the specimens were seen on the ground; due to the fact that the environment was not modified during the observations, it could not be distinguished if this was due to egg laying or to a habit of safeguarding and/or rest. At the conclusion of the test, eggs were collected from a state of incubation (buried), as underground egg laying and protection is described in the literature (Lagrifa, 2002; San Román et al., 2004).

Between 9 and $16 \%$ of the individuals were classified in the "In the water" category (Table 1), since they were found on the water supply trays. In systems with supplementation of balanced feed, it is recommended that the snails have drinking water available (Lagrifa, 2002).

The scarce number of specimens observed to be adhered to the netting (from $0 \%$ to $3 \%$ ), allows for the inference that they did not attempt to abandon the cubicles. Escape attempts in outdoor system premises are commonly reported in the literature. (Lagrifa, 2002; San Román et al., 2004; González et al., 2005; Vieites, 2007). It is presumed that the desire for escape could be caused by scarcity of food (Lagrifa, 2003), or by other factors, which have rarely been studied in snails in captivity, such as intraspecific competition, the high density of individuals, or the attempt to escape from an unfavorable environment.

From the analysis of the results obtained in this test, it can be concluded that if densities of less than 200 snails $\cdot \mathrm{m}^{-2}$ are used, as is commonly found in outdoor systems in the fattening stage, the individuals will use the available space in a similar manner, expressing similar behavior patterns and low escape attempts.

\section{Acknowledgment}

The authors wish to thank Juan Rusinek for his donation of the $H$. aspersa specimens used in this study that came from his property.

\section{Resumen}

O. González, G. Pérez Camargo, M. Membiela, D. Frezza, N. Bartoloni y C. Vieites. 2009. Observaciones discretas de la distribución espacial de caracoles en terminación Helix aspersa en sistema abierto. Cien. Inv. Agr. 36(1):123-130. Con el objeto de contribuir al conocimiento de la distribución espacial y de ciertas pautas de comportamiento de caracoles de Helix aspersa en sistema abierto, se observaron con frecuencias previamente establecidas tres densidades de caracoles adultos en terminación. Entre el 8 de noviembre y el 18 de diciembre 
del año 2006, se alojaron en nueve cubículos aleatoriamente con tres repeticiones, 50, 100 y $200 \mathrm{caracol} \cdot \mathrm{m}^{-2}$ en la fase final de engorde. Se realizaron 12 observaciones entre las 12 a.m y las 13 a.m. Las categorías seleccionadas como actos discretos correspondieron a observar a los ejemplares en los refugios, sobre las hojas de acelga, adheridos a la red, sobre el alimento balanceado, en la bandeja de suministro de agua y en el suelo. Se realizó un análisis estadístico de las interacciones densidad $\mathrm{x}$ categoría $\mathrm{x}$ tiempo por medio de pruebas de frecuencias marginales y parciales. Se concluyó que en horas del mediodía la mayoría de los caracoles permanecían en los refugios artificiales y en las hojas de monocultivo de acelga y no se detectaron diferencias para el resto de las categorías respecto de la distribución espacial de los individuos en las tres densidades analizadas. Si se emplean densidades menores a la mayormente utilizada en sistema abierto para la etapa de engorde $\left(200 \mathrm{caracol} \cdot \mathrm{m}^{-2}\right)$ los individuos utilizarían de manera semejante el espacio disponible expresando pautas comportamentales similares.

Palabras clave: Helicicultura, Helix aspersa, caracoles, distribución espacial.

\section{References}

Agresti, A. 1996. An Introduction to Categorical Data Analysis. Wiley-Interscience. USA. 290 p.

Arditi, A., D. Rodríguez, and R. Villar. 2003. Plan de negocios para la cría, procesamiento y comercialización de caracoles Helix aspersa. Tesina, Universidad Centro de Estudios Macroeconómicos. Buenos Aires, Argentina. 150 p.

Arnaud, J., L Madec, A. Guiller, and J. Deunff. 2003. Population genetic structure in an human-disturbed environment: a case study in the land snail Helix aspersa (Gastropoda:Pulmonata). Heredity 90:451-458.

Arrébola Burgos, J. 2001. La explotación de los caracoles terrestres en España: aspectos biológicos y socioculturales. Temas de Antropología Aragonesa $\mathrm{N}^{\mathrm{o}} 11$ p. $139-172$.

Arrébola Burgos, J. 2004. Bases para la Conservación y Explotación Sostenible de los Caracoles Terrestres en la Provincia de Cádiz (España). Boletín de la Sociedad Gaditana de Historia Natural. p. 63-81.

Arrébola Burgos, J., A. Porras, A Cárcaba, and A.Ruiz, 2004. Caracterización del sector helicícola andaluz: la captura de caracoles terrestres en Andalucía occidental. Sociedad Española de Malocología Española. Iberus 22:31- 41

Baur, B. 1992. Patterns of dispersion, density and dispersal in alpine populations of the land snail Arrianita arbustorum (L.) (Helicidae). Ecography 9:117-125.

Cameron, R., and M. Carter. 1979. Intra and interspecific effects of population density on growth and activity in some helicid land snails (Gastropoda: Pulmonata). Journal of Animal Ecology 48:237246.

Dupont-Nivet, M., V. Coste, P. Coinon, J. Bonnet, and J. Blanc. 2000. Rearing density effect on the reproduction performance of the edible snail $\mathrm{He}$ lix aspersa Muller in indoor rearing. Annales de Zootechnie. 49:447-456.

González, O.M. 2007. El comportamiento animal y las especies animales alternativas. Agronegocios Alternativos. Cap. IV. Pag 107-126. Editorial Hemisferio Sur. Argentina.

González, O.M, C. Basso, and C. Vieites. 2005. Actividad helicícola en la Argentina: actualidad y acciones futuras. Revista FAUBA (Argentina) 25: 83-91.

González, O.M; G. Pérez Camargo, M. Membiella; D. Frezza; N. Bartoloni, and C. Vieites. 2008. Efecto de la densidad poblacional en la productividad de caracoles (Helix aspersa) en un sistema a cielo abierto alimentados con acelga y suplemento alimentario balaceado. Cien. Inv. Agr. 35:205-212.

Grandin, T. 2002. Entender la motivación animal. Rural Heritage 27:22-23.

Lagrifa, 2002. Helicicultura: cultivo del caracol terrestre. Editorial Propia. La Plata. Argentina 116 p.

Lahitte, H., H. Ferrari, and L. Lazaro, 2002. Sobre el etograma, 1: del etograma como lenguaje al lenguaje de los etogramas. Revista de Etología 4:129-141.

Madec, L., C. Desbusquois, and M. Coutelleg-Vreto. 2000. Phenotypic plasticy in reproductive traits: importance in the life history of Helix aspersa 
(Mollusca: Helicidae) in a recently colonized habitat. Biological Journal of the Linnean Society 69:25 39.

Mayoral, A.G, A. Garcia, J. Perea, R. Martín, R. Martos, R. Acero, and F. Peña. 2004. Efecto de la densidad de población sobre el tamaño del caracol Helix aspersa Müller. Archivos de Zootecnia 53:379-382.

Navarro Maestre, M., and D. Vázquez. 2000. Acercamiento al estrés. Instituto superior de Ciencias Médicas de La Habana. Cuba.

http://fcmfajardo.sld.cu/jornada/trabajos/estresII. html (Consultado: Julio 2007).

Perea Muñoz, J., F. Peña Blanco, M. Herrera García, A. García Martinez, and D. Cabbera. 2005. Diseño experimental en evaluación de preferencias en la selección de hábitat (Revisión I). Producción Animal y Gestión. http://www.uco.es/zootecniaygestion/img/datos/24_11_46_comportamiento.pdf (Consultado: Julio 2007).
Perea, J. R. Martín, R. Acero, F. Goméz, A.M. García Mayoral, F. Peña, and A. García. 2006. Selección de hábitat en caracoles terrestres y sus aplicaciones a la helicicultura. Archivos de Zootecnia 55 (R): 1-12.

San Román, J., G. Giammarino, and S. Vidal. 2004 Manual helicícola: cría de caracoles a cielo abierto. Editorial Orientación Gráfica, Buenos Aires. Argentina. 175 p.

Slideshare. 2007. Comportamiento: Método científico en etología. http://www.slideshare.net/jfreire/ metodologia-observacional. (Consultado agosto 2007).

Vieites C.M., O.M. González, and C. Acuña Seery. 2007. Producciones Animales Alternativas con Potencial de Desarrollo Mediato e Inmediato en la Argentina. Estudio 1.EE.152. Unidad de Preinversión (UNPRE). Banco Interamericano de Desarrollo. Editorial Fundación I+I. Buenos Aires, Argentina. 185 pp. 
